\title{
Proposal to Reject the New Combination Yersinia pseudotuberculosis subsp. pestis for Violation of the First Principle of the International Code of Nomenclature of Bacteria
}

\author{
Request for an Opinion
}

\author{
JAMES E. WILLIAMS \\ Department of Hazardous Microorganisms, Walter Reed Army Institute of Research, Washington, D.C. 20307
}

It is proposed that the name Yersinia pseudotuberculosis subsp. pestis, for the organism also known by the valid name Yersinia pestis, violates Principle 1, Subprinciple 2, of the International Code of Nomenclature of Bacteria and should be rejected.

The Approved Lists of Bacterial Names (5) includes Yersinia pestis (Lehmann and Neumann 1896) van Loghem 1944 for the causative agent of plague and Yersinia pseudotuberculosis (Pfeiffer 1889) Smith and Thal 1965 for the causative agent of pseudotuberculosis. In 1981, the new combination Yersinia pseudotuberculosis subsp. pestis (Lehmann and Neumann) Bercovier et al. 1981 was validly published for the pathogen of plague (3). As a consequence, a subspecies was automatically created for the pseudotuberculosis bacillus, giving Yersinia pseudotuberculosis subsp. pseudotuberculosis (Pfeiffer) Smith and Thal 1965. The new names do not invalidate the earlier names (4), so there are presently two valid ways to refer to each of these human pathogens.

Uncertainty has arisen about which names should be used (2). In fact, it now depends upon personal preference or institutional policy. The Centers for Disease Control in the United States continue to use the older names (2), whereas the World Health Organization is using the newer names $(6$, 7).

Plague is now being reported as a disease arising from infection with both $Y$. pestis and a subspecies of $Y$. pseudotuberculosis. As a result, considerable confusion can arise about what constitutes a focus of pseudotuberculosis infection. Some regions with plague that are free of the disease called pseudotuberculosis have suddenly become endemic for $Y$. pseudotuberculosis, if one prefers the newer terminology. More importantly, use of the new names may cause errors leading to accidental plague infections that could threaten public health and cost lives (6). Such accidents might arise by misreading labels on plague cultures that properly list the new name or from labels on plague cultures that omit, or have lost, the subspecies epithet pestis. This potential will be exacerbated if the name $Y$. pseudotuberculosis continues to be used without a subspecies epithet, as there will be less tendency to question and identify mislabeled cultures of the plague bacillus. In effect, authorities who recommend use of $Y$. pseudotuberculosis without a subspecies epithet are inadvertently contributing to the potential for laboratory accidents.

A nomenclatural consideration is that $Y$. pestis is the type species of the genus. Subordination of the type specific epithet might affect the validity of the genus depending upon whether the epithet or the genetically homologous cultures themselves are considered to represent the type species

\footnotetext{
* Corresponding author.
}

concept. This question is trivial and academic compared with the practical hazards that attend acceptance of subspecies rank for $Y$. pestis. Although deoxyribonucleic acid homology data have come to be generally accepted as evidence for species membership, it might be argued that in this exceptional case the highly infectious characteristic, which differentiates these two distinct entities, is of sufficient scientific and practical importance to merit recognition at the species level. In this case a ruling to conform to the First Principle of the International Code of Nomenclature of Bacteria could be of critical importance.

My position is that $Y$. pestis is the only suitable name for the plague bacillus strictly as a matter of nomenclature and that the accepted official use of that name, conserved for reasons of human safety, does not negate or reflect in any way upon the close genetic and taxonomic relationships that have been established between $Y$. pseudotuberculosis and $Y$. pestis (1).

In summary, the name $Y$. pseudotuberculosis subsp. pestis can cause confusion with dire consequences for public health. Principle 1, Subprinciple 2, of the International Code of Nomenclature of Bacteria is to "avoid or reject the use of names which may cause error or confusion," and General Consideration 6 of the Code indicates that Principles take precedence over the Rules (4). Avoidance of this new name for the plague bacillus would probably prove ineffective. The potential for life-threatening mishaps would persist long into the future. Should an accident occur, the scientific community and public health officials could be discredited for creating a human hazard that was foreseen $(1,2)$ and should have been prevented. Therefore, it is respectfully requested that the Judicial Commission, as the responsible authority, issue an Opinion to reject the name Yersinia pseudotuberculosis subsp. pestis for violation of the First Principle of the Code.

\section{LITERATURE CITED}

1. Bercovier, H., H. H. Mollaret, J. M. Alonso, J. Brault, G. R. Fanning, A. G. Steigerwalt, and D. J. Brenner. 1980. Intra- and interspecies relatedness of Yersinia pestis by DNA hybridization and its relationship to Yersinia pseudotuberculosis. Curr. Microbiol. 4:225-229.

2. Brenner, D. J., J. C. Feeley, and R. A. Feldman. 1982. Confusion in bacterial nomenclature. ASM News 48:511-512.

3. International Journal of Systematic Bacteriology. 1981. Validation of the publication of new names and new combinations previous- 
ly effectively published outside the IJSB. List no. 7. Int. J. Syst. Bacteriol. 31:382-383.

4. Lapage, S. P., P. H. A. Sneath, E. F. Lessel, V. B. D. Skerman, H. P. R. Seelinger, and W. A. Clark (ed.). 1975. International code of nomenclature of bacteria. 1975 Revision. American Society for Microbiology, Washington, D.C

5. Skerman, V. B. D., V. McGowan, and P. H. A. Sneath (ed.).
1980. Approved lists of bacterial names. Int. J. Syst. Bacteriol. 30:225-420.

6. Williams, J. E. 1983. Warning on a new potential for laboratoryacquired infections as a result of the new nomenclature for the plague bacillus. Bull. W. H. O. 61:545-546.

7. World Health Organization. 1981. Weekly Epidemiol. Rec. 50:400. 